the acute stage of strumous, phlyctenular corneitis, remoring the vascularity more expeditely than any other remedy that I have hitherto employed, and probably tending to contraction of the resulting ulcer, and by its combination with the aqueous solution of belladonna, \&c., soothes and relieves the intolerance of light; though it has usually been my practice to employ the stimulating mode of treatment as soon as the fasciculi of vessels had disap. peared. I have also been careful to secure a suitable regimen, and a dose of aperient medicine when such was doemed necessary.Medical Times and Gazette.

\title{
SOME ACCOUNT OF PAULLINIA SORBILIS AND ITS PRODUCTS.
}

\section{BY T. C. Anchen, EsQ.}

The author remarked:-There is no more remarkable plant in the Order Sapindacex, if regarded from an economic point of view, than Puullinia sorbilis, although, as a plant, it is not wcll known to the botanical world. From its large secds is manufactured the substance called "Guarana," which is extensirely used in Brazil, Guatemala, Costa-Rica, and other parts of South America, as a nervous stimulant and restorative. The seeds, deprived of their coverings, are pounded into a paste, which, hardened in the sun, constitutes Guarana. It is used both as a remedy for rarious discases, and also as a material for making a most refreshing beverage; and it adds another of thcse incidents so puzzling in human history of the discovery of such qualities in plants least likely to be suspected: such, for instance, as that the leaves of Tea, the seeds of Coffee and Cacao, the leaves and twigs of the various American Ilexes, and other plants, should havo this wonderful restorative effect on the nervous system; and that this should not be a mere vague no. tion, such as attaches to thousands of other plants, but that it should really depend upon the presence of a chenical principle, the same in all, and the opcration of which can be satisfactorily explained. 'The presence of an alkaloid, which he called Guaranine, was discovered some years ago in Guarana, by Dr. Theodore von Martius, of Erlangen, but its identity with Theine was soon cstablished, and subsequent analyses, especially one by Dr. Stenhouse in 1856, proved that not only was the active principle of Guarana identical with Theine, but that, as far as is known, no other substance yiclds it so abundantly, the amount being 5.07 per cent. as against good black tea, which yields $2 \cdot 13$, and coffce from 0.8 to 1.00 . The mode of using the Guarana is curious and interesting. It is carried in the pocket of almost erery traveller, and with it the palate hone or a scale of the large fish (Sudis gigus), locally called " pi. rarucu," the rough surfaces of which form a rasp upon which the Guarana is grated, and a few grains of the powder so formed are 
added to water, and drunk as a substitute for tea. The effect is very agrceable, but as there is a large portion of tannic acid also present, it is not a good thing for weak digestions. Its remarkably restorative power has giren it a further great reputation as an aphrodisiac. Another species of this genus, Paullinia cupana, also enters into the composition of a favorite national diet-drink. Its sceds are mingled with cassava and water, and allowed to pass into a state of fermentation, bordering on the putrefactive, in which state it is the farorite drink of the Orinoco Indians.-American Journal of Pharmacy, from London Pharmacentical Journal, Sept., 1863, from Procedings of the Botanical Socicty of Edinburgh, in Gardencrs' Chronicle.

\section{THE BOSTON MEDICAL AND SURGICAL JOURNAL.}

BOSTON: THURSDAY, JANUARY $21,1864$.

The Malden Murder and Coroners. - The recent mjsterious murder at Malden, with the equally inexplicable blundering at the inquest and subsequent judicial investigation, must convince everybody, we think, that there must be something at fault in the initial processes of our criminal law. In the very centre of a populous town, at nooriday, and in the most open and public building of the place, a young man is quietly murdered. Citizens had visited the bank but a few minutes before the commission of the deed, and had left young Converse at his desk, and not long afterwards a lad entering found him lying on the floor and groaning. The murderer went, as he came, unseen and unsuspected, and is still unknown. The victim survived his injuries nearly an hour, but did not recover his consciousness. Two wounds were found upon the head, one in the left temple, the other behind the right ear, and of one or both of these he died. As to the precise nature of them we are still unfurtunately in doubt, for the two physicians by whom the murdered man was seen give very different descriptions of their appearance. They did agrce, however, upon one point-that death had been caused by shooting.

It is not our intention to criticize the medical testimony in this case, for we hold it is never just to form an opinion of professional evidence from newspaper reports alone, and although it would scem fair to infer from the data we have, that the examination of the wounds was not conducted with sufficient care or minuteness by either gentleman, still this is no ground for the ungentlemanly abuse of them which has been lately expressed at great length in one of our leading daily papers, in a communication which exhibits sufficient ignorance of the professional points the writer attempts to throw light upon, to indicate at once the profession to which he belongs. It is to the proceedings of the inquest that we wish to call the particular attention of our readers, as they afford a fair example of the way in which justice must be thwarted in these really important preliminary investigations, unless the coroner has a scientific education. Here was a man mysteriously 